RESEARCH ARTICLE

Dogan Akdogan ${ }^{1}$

${ }^{1}$ Pursaklar State Hospital Department of Medical Microbiology, Ankara, Turkey

Corresponding Author:

Dogan Akdogan

Pursaklar State Hospital

Department of Medical

Microbiology, Ankara, Turkey

Phone:+90 5320579751

mail:dr.dakdogan@hotmail.com

Received: 23.08.2021

Acceptance: 24.09 .2021

DOI: $10.18521 / \mathrm{ktd} .986150$

Konuralp Medical Journal e-ISSN1309-3878

konuralptipdergi@duzce.edu.tr konuralptipdergisi@gmail.com www.konuralptipdergi.duzce.edu.tr

\section{Surveillance Analysis and Microbiological Profiles of Nosocomial Infections in A Palliative Care Center ABSTRACT}

Objective: Despite the wide availability of palliative care units in several countries, they have been founded in our country recently. This study aimed to contribute to the development of appropriate treatment protocols by determining the causes of hospitalizations, comorbidities, infection rates, and causative microorganisms in a palliative care center.

Methods: Blood cultures were taken from the patients suspected to have developed nosocomial infections. Samples for cultures were taken from the foci that were thought to be the origin of infection. Identification of isolates was performed using automated systems and conventional methods. The numbers of patients and patient days, and the numbers and rates of nosocomial infections were retrieved from the infection control unit data records and were analyzed. The rates and incidences of nosocomial infections in our hospital and the palliative care unit were calculated.

Results: Of the patients, $51 \%$ were men and $49 \%$ were women. The mean age was $72 \pm 12.6$ years. Nosocomial infection rates were $6.3 \%$ in $2019,9.1 \%$ in 2020 , and $3.3 \%$ in the first six months of 2021. Urinary system infections ranked first with a rate of $58.6 \%$. The most common cause of hospital admissions was malignancy with a rate of $25.9 \%$. The most commonly isolated microorganism was Klebsiella spp with a rate of $27.5 \%$.

Conclusions: Palliative care aims to improve symptoms and the quality of life of patients. Our study has contributed to developing practical solutions by documenting prognostic factors, infections, causative microorganisms, and issues experienced in palliative care patients.

Keywords: Palliative Care, Infection, Surveillance, Microbiological Profile.

\section{Palyatif Bir Bakım Merkezinde Hastane Enfeksiyonlarının Sürveyans Analizi Ve Mikrobiyolojik Profilleri ÖZET}

Amaç: Global olarak yaşlı nüfustaki ve kronik hastalıklardaki artış, palyatif bakım ihtiyacını artırmaktadır. Dünyada Palyatif bakım birimleri yaygın olmakla birlikte ülkemizde birçok hastanede yeni açılmaktadır. Bunun için bu merkezlerde takip edilen hastaların, yatış sebepleri, komorbiditeler, enfeksiyon hızları ve etken mikroorganizmalar belirlenerek uygun tedavi protokollerinin oluşturulmasına katkı sağlanması amaçlandı.

Gereç ve Yöntem: Palyatif bakım ünitesinde yatan 457 hasta değerlendirildi. Hastane enfeksiyonu geliştiği düşünülen hastalardan kan kültürü ile birlikte enfeksiyon olduğu düşünülen odaklardan kültürler alındı. İzolatların tanımlanması otomatize sistemler ve conventional yöntemler kullanılarak yapıldı. Enfeksiyon kontrol birimi kayıtlarından hasta sayısı, hasta günü sayıları, hastane enfeksiyonu sayısı, hastane enfeksiyonu hızı verileri incelendi. Hastanemizdeki ve palyatif bakım ünitesindeki hastane enfeksiyon oranları ve insidansları hesapland1.

Bulgular: Hastaların \%51'i erkek, \%49'u kadın, yaş ortalaması 72 $\pm 12,6$ olarak bulundu. Hastane enfeksiyonu hızı 2019 yılında \% 6,3, 2020 yılında \%9,1 ve 2021 yılının ilk altı ayında \%3,3 olarak hesaplandı. Üriner sistem enfeksiyonları \%58,6 ilk sırayı alırken, en sık görülen yatış tanısı \%25,9 oanı ile malignite idi. En çok izole edilen mikroorganizma ise $\% 27,5$ oran1 ile Klebsiella spp idi.

Sonuç: Palyatif bakım, güçlü koordinasyon ve işbirliği gerektiren multidisipliner uygulamaları içerir. Palyatif bakım, hastaların semptomlarını iyileştirmeyi ve hayat kalitelerini artırmayı amaçlamaktadır. Çalışmamız, palyatif bakım hastalarının problemlerini, prognostik faktörleri, enfeksiyonları ve etken mikroorganizmaları dokümente ederek, bu hastalar için pratik çözümler geliştirilmesine katkı sağlamıştır.

Anahtar Kelimeler: Palyatif Bakım, Enfeksiyon, Sürveyans, Mikrobiyolojik Profil. 


\section{INTRODUCTION}

The World Health Organization describes palliative care as a comprehensive approach to improve the quality of life for patients and their families when they face a terminal disease. The primary goal of palliative care is to provide a multidisciplinary approach that focuses on providing the best possible quality of life through early diagnosis, assessment, and treatment for physical, mental, psychological, and social problems experienced by patients and their families. Palliative care aims to relieve distress in all stages of the disease. Palliative care can be provided simultaneously along with curative or lifeprolonging treatments $(1,2)$. The need for palliative care is increasing in parallel to the aging population in our country and in the world. Diseases treated in palliative care include cancers, central and peripheral neuronal diseases, muscle diseases, organ failures, and irreversible trauma damage $(2,3)$. Palliative care patients are highly susceptible to infections. Infection increases the symptom burden and further reduces the quality of life. The diagnosis of infection is difficult in palliative care patients because of multiple comorbidities, the absence of clinical signs, or the presence of symptoms too vague to be recognized (3). Nosocomial infections (NIs), also called hospitalacquired infections, are not present at the time of admission but develop while the patient receives healthcare services. Invasive procedures and surgery or the placement of permanent medical or prosthetic devices are associated with NIs in the era of modern healthcare. NIs constitute a major health issue worldwide as they do in our country, increasing morbidity and mortality rates, treatment costs, and the length of hospital stay (4). Antibioticresistant microorganisms constitute a major problem in the fight against NIs. Options for antibiotherapy are limited to treat infections caused by antibiotic-resistant microorganisms. It is of great importance that relevant staff in a healthcare center should be aware of microorganisms, which are isolated as the causative agents of infections in that specific health center $(4,5)$.

Our aim in this study is to contribute to the establishment of appropriate treatment protocols by determining the causes of hospitalizations, comorbidities, infection rates, causative microorganisms, and the distribution of hospital infections according to the body systems in patients treated in an adult palliative care center.

MATERIAL AND METHODS

A total of 457 patients; who were treated in Ankara Pursaklar Public Hospital's palliative care unit in the period between January 2019 and June 2021, were reviewed for the occurrence of NIs and the retrieved information was analyzed. The study was commenced after obtaining approval from Ankara Numune Training and Research Hospital's Ethics Committee ( 23.08.2021-E-41303261-799). Samples for blood culture tests and samples for relevant culture tests from suspected foci of infections were obtained from patients; who were suspected to have developed NIs. The identification of isolates was performed using Phoenix (Becton Dickinson, ABD) automated systems and conventional methods. Patients meeting the criteria for the diagnosis of NIs were enrolled. The diagnosis of NIs was made based on the diagnostic criteria published by the "Centers for Disease Control and Prevention" (CDC) (6). The numbers of patients, patient days, and the number and rate of NIs were retrieved from the infection control unit data records and analyzed. The rates and incidences of NIs in our hospital and palliative care unit were calculated. Incidences of NIs were calculated by the formula below:

NI incidence $(\%)=$ (Number of NI diagnosed in a specified period / Number of inpatients in the same specified period) x 100 (7). Data were analyzed using SPSS 18.0 version software (SPSS Inc, Chicago, USA). Categorical variables and frequency distributions were summarized as numbers and percentages. Nominal variables were summarized as mean \pm standard deviation.

\section{RESULTS}

In the years 2019 - 2021, a total of 7.795 patients were hospitalized. NI rates were $2.63 \%$ in $2019,1.22 \%$ in 2020 , and $0.67 \%$ in the first six months of 2021. The distribution of NIs by years is presented in Table 1.

Table 1. Distribution of Nosocomial Infections by Years

\begin{tabular}{cccccc}
\hline Year & $\begin{array}{c}\text { Number of } \\
\text { Patients }\end{array}$ & $\begin{array}{c}\text { Number of } \\
\text { Patient Days }\end{array}$ & $\begin{array}{c}\text { Number of } \\
\text { Infections }\end{array}$ & $\begin{array}{c}\text { NI Rate } \\
(\boldsymbol{\%})\end{array}$ & $\begin{array}{c}\text { Incidence Density } \\
\text { of NI (\%) }\end{array}$ \\
\hline $\mathbf{2 0 1 9}$ & 2.742 & 27.749 & 72 & 2.63 & 2.91 \\
\hline $\mathbf{2 0 2 0}$ & 3.119 & 33.248 & 38 & 1.22 & 1.14 \\
\hline $\mathbf{2 0 2 1}$ (first 6 months) & 1.934 & 14.697 & 13 & 0.67 & 0.88 \\
\hline
\end{tabular}

Of the 457 patients treated in the palliative care unit, $174(51 \%)$ were men and $145(49 \%)$ were women. The mean age was $72 \pm 12.6$ years. The NI rates in the palliative care unit were calculated as
$6.34 \%$ for the year $2019,9.16 \%$ for 2020 , and $3.31 \%$ for the first six months of 2021. The distribution of NIs in the palliative care center by years is presented in Table 2 . 
Table 2. Distribution of nosocomial infections in the palliative care center by years

\begin{tabular}{cccccc}
\hline Year & $\begin{array}{c}\text { Number of } \\
\text { Patients }\end{array}$ & $\begin{array}{c}\text { Number of } \\
\text { Patient Days }\end{array}$ & $\begin{array}{c}\text { Number of } \\
\text { Infections }\end{array}$ & $\begin{array}{c}\text { NI Rate } \\
(\boldsymbol{\%})\end{array}$ & $\begin{array}{c}\text { Incidence Density } \\
\text { of NI (\%) }\end{array}$ \\
\hline $\mathbf{2 0 1 9}$ & 205 & 5.344 & 13 & 6.34 & 2.43 \\
\hline $\mathbf{2 0 2 0}$ & 131 & 4.956 & 12 & 9.16 & 2.42 \\
\hline $\mathbf{2 0 2 1}$ (first 6 months) & 121 & 1.928 & 4 & 3.31 & 2.07 \\
\hline
\end{tabular}

The most common NIs in the three-year study period were urinary system infections $(58.6 \%, \mathrm{n}=17)$, circulatory system infections $(37.9 \%, \mathrm{n}=11)$, and skin and soft tissue infections $(3.4 \%, \mathrm{n}=1)$ in decreasing order of frequency. The most common three diagnoses and comorbidities were malignancies with a rate of $25.9 \% \quad(n=66)$, respiratory system diseases with a rate of $18.8 \%$ $(\mathrm{n}=48)$, and cardiovascular system diseases with a rate of $12.9 \%(n=33)$. The causes of admission to palliative care are shown in Table 3.

Table 3. Causes of hospitalization in patients admitted to the palliative care unit.

\begin{tabular}{lcc}
\hline Cause of hospitalization & n & \% \\
\hline Malignancy & 66 & 25.9 \\
\hline Respiratory system disease & 48 & 18.8 \\
\hline Cardiovascular system disease & 33 & 12.9 \\
\hline Cerebrovascular disease & 28 & 11.0 \\
\hline $\begin{array}{l}\text { Neurodegenerative diseases (dementia } \\
\text { and/or Parkinson's disease) }\end{array}$ & 19 & 7.4 \\
\hline Nutritional disorders & 17 & 6.6 \\
\hline Diabetes and associated complications & 13 & 5.1 \\
\hline Miscellaneous & 30 & 11.8 \\
\hline Total & 254 & 100 \\
\hline
\end{tabular}

Twenty-nine microorganism species were isolated from patients diagnosed with NIs in the palliative care center. The most commonly isolated microorganism was Klebsiella spp with a rate of 27.5\%. Acinetobacter spp and Escherichia coli were the second and third most common species isolated with rates of $20.6 \%$ and $13.7 \%$, respectively (Table-4).

Table 4. Distribution of microorganisms as causative agents of nosocomial infections in the palliative care

\begin{tabular}{lcc}
\hline Microorganism & (n ) & \% \\
\hline Klebsiella spp. & 8 & 27.5 \\
\hline Acinetobacter spp & 6 & 20.6 \\
\hline Escherichia coli & 4 & 13.7 \\
\hline Pseudomonas spp. & 4 & 13.7 \\
\hline Pseudomonas aeruginosa & 3 & 10.3 \\
\hline Proteus spp. & 2 & 6.8 \\
\hline Staphylococcus aureus & 1 & 3.4 \\
\hline Streptococcus pneumoniae & 1 & 3.4 \\
\hline Total & 29 & 100 \\
\hline
\end{tabular}

\section{DISCUSSION}

Palliative care is a multidisciplinary system that aims to improve the quality of life in progressive, incurable, and fatal diseases. Advances in modern medicine have offered many improvements in living conditions and increased the life expectancy of persons with chronic and fatal diseases $(1,8)$. However; interventions for diagnosis and treatment, comorbidities, and treatment protocols for comorbid diseases weaken the immune system and increase the risk of NIs. Surveillance of causative infectious agents should be performed, necessary measures should be implemented, and infection control plans should be developed accordingly in order to control NIs (9). Although NI rates in our country vary from $1.0 \%$ to $8.6 \%$, NIs usually occur in $5-10 \%$ of hospitalized patients $(9,10,11)$. In our study, this rate was found in the range between $1.2 \%$ and $2.6 \%$. In a study conducted on adult patients admitted to a palliative care center (12), this rate was $10.8 \%$. Another study (9) reported rates varying from $6.6 \%$ to $4.7 \%$ in palliative care patients. In our study, NI rates in the palliative care unit were in the range between $6.34 \%$ and $9.16 \%$, which were higher than the overall NI rates in the hospital similar to the reports in previous studies (Table-1, Table-2). We think that treatment interventions, comorbidities, and a compromised immune system increase the patients' risk of developing NIs.

The evaluation of demographic data showed that $51 \%$ of our palliative care patients were men and $49 \%$ were women, with a mean age of $72 \pm 12.6$ years. In the study performed by Dinçer et al., 59\% of the patients were men and $41 \%$ were women, with a mean age of $70.6 \pm 17.2$ years (12). In the study performed by Yürüyen et al., $55 \%$ of the patients were men and $45 \%$ women, with a mean age of $71 \pm 15.8$ years (13). Thus, our study was compatible with the literature in terms of demographic findings.

In our study, it was determined that the most common reason for hospitalization was malignancy. Respiratory system diseases were the second and cardiovascular system diseases were the third most common causes of hospital admissions (Table-3). In the study conducted by Komaç et al., patients received treatment for malignancy, followed up for the completion of long-term antibiotic therapy, and given treatment for diabetes and complications at rates of $33 \%, 17 \%$, and $17 \%$ respectively (14). The study performed by Turgut et al. reported that patients were followed up for malignancy, cerebrovascular diseases, and cognitive disorders at rates of $28.5 \%, 25.5 \%$, and $17.6 \%$, respectively (15). In the study by Yürüyen et al., the three most common causes for treatment were malnutrition, malignancy, and infections at rates of 59\%, 44\%, 
and 33\%, respectively (13). A study performed by Dinçer et al. reported that $52.2 \%$ of the patients were followed up for nutritional support, $40.5 \%$ for pressure sores, $42.3 \%$ for neurological disease, and $23.4 \%$ of the patients were followed up for cancer (12). Another study reported the most common causes for hospital admissions as cerebrovascular disease, malignancy, and cardiovascular disease at rates of $22.15 \%, 20.8 \%$, and $15 \%$, respectively (8).

When we examined the distribution of nosocomial infections by body systems in palliative care patients, urinary system infections were found to take the first rank with a rate of $58.6 \%$. Blood circulation infections and skin and soft tissue infections took the second and third ranks with rates of $37.9 \%$ and $3.4 \%$, respectively. Chun et al. found the following such rates as $51.4 \%, 21.4 \%$, and $25.7 \%$ for infections of the respiratory, gastrointestinal, and urinary systems, respectively (16). In another study, microbial growth in culture tests was reported to have occurred in the samples collected from the urinary tract, the respiratory tract, the blood, and the skin and subcutaneous tissues at rates of $42.5 \%, 22.9 \%, 12.5 \%$, and $12.5 \%$, respectively (17). Dağl1 et al. detected urinary tract infections, respiratory tract infections, and blood circulation infections at rates of $45.1 \%, 42.5 \%$, and $16.8 \%$, respectively (18). Akdoğan et al. found out that growth occurred in urine, blood, and wound culture tests at rates of $67.9 \%, 32.1 \%$, and $30.2 \%$, respectively (19). In this study, the most commonly isolated microorganisms from patients diagnosed with NIs in the palliative care unit were Klebsiella spp. with a rate of $27.5 \%$, Acinetobacter spp. with a rate of $20.6 \%$, and E.coli with a rate of $13.7 \%$ (Table-4). Pereira $\mathrm{J}$ et al. isolated E. coli,
Staphylococcus aureus, and Enterococcus spp at rates of $22.9 \%, 20.0 \%$, and $11.4 \%$, respectively (17). Another study reported the isolated microorganisms as Klebsiella spp, Pseudomonas spp, and Staphylococcus spp at rates of $28.3 \%$, $27.4 \%$, and $22.1 \%$, respectively (18). Another study reported $E$. coli as the most commonly isolated microorganism (20).

In conclusion, patients followed in the adult palliative care center were mostly geriatric cancer patients. Urinary system infections ranked first among all NIs. NIs constitute a major problem in our hospital similar to the worldwide data. NIs are critically important quality indicators of healthcare. Rates of NIs vary across countries, regions, and hospitals. Hospital administrators should identify causative microorganisms and determine the distribution of infections in the respective hospital so that antibiotics are used appropriately and NIs can be kept under control. The Infection Control Committee in our hospital monitors and analyzes infection rates. Using the results, infection rates specific to our hospital are found and the clinical units at high risk are identified. Subsequently, infection control measures are revised and implemented accordingly. Surveillance studies are essential to keep NIs under control. Surveillance studies guide the identification of actual problems and the evaluation of the success of implemented policies. Besides the surveillance studies for NIs in palliative care, in this study, we have contributed to the development of practical solutions for the wellbeing of patients by documenting prognostic factors, infection types, causative microorganisms, and problems experienced in our patients.

\section{REFERENCES}

1. WHO. Palliative Care. [Internet]. [cited 2021 August 15].Available online: https://www.who.int/newsroom/fact-sheets/detail/palliative-care5 (accessed on August 2021)

2. Dincer M, Kahveci K, Döğer C, Gökçınar D, Yarıcı AK, Taş H. Factors affectıng the duratıon of admıssıon and discharge in a pallıatıve care center for gerıatrıc patıents. Turkish Journal of Geriatrics 2016;19(2):74-80

3. Macedo F, Bonito N. Current opinion about antimicrobial therapy in palliative care: an update. Current opinion in oncology. 2019;31(4):299-301.

4. Alp E, Leblebicioglu H, Doganay M, Voss A. Infection control practice in countries with limited resources. Annals of clinical microbiology and antimicrobials. 2011;10(1):1-4.

5. Vasudevan A, Mukhopadhyay A, Li J, Yuen EGY, Tambyah P A. A prediction tool for nosocomial multidrug resistant gram-negative bacilli infections in critically ill patients-prospective observational study. BMC infectious diseases.2014;14(1);1-10.

6. Horan TC, Andrus M, Dudeck MA. CDC/NHSN surveillance definition of health care-associated infection and criteria for specific types of infections in the acute care setting. American journal of infection control. 2008;36(5):309-32.

7. Widmer AF. Infection control and prevention strategies in the ICU. Intensive care medicine. 1994;20(4):711.

8. Cadircin D, Ayazoz Y, Kocakoglu S. Evaluatıon Of Patıents Followed In A Palliatıve Care Unıt In Turkey. Turkish Journal of Geriatrics.2021;24(2):227-34.

9. Şentaş S, Kahveci K. Surveillance of hospital infections in longterm intensive care unit and palliative care centre: a 3-year analysis. J Contemp Med. 2018; 8: 55-9.

10. Karahocagil MK, Yaman G, Göktaş U, Sünnetçioğlu M, Çıkman A, Bilici A, et al. Determination of hospital infection pathogens and resistance profile.Van Tıp Dergisi.2011; 18 (1):27-32. 
11. Erdin FS, Yetkin MA, Hatipoglu CA, Yucel M, Karakoc AE, Cevik MA, et al. Five-year surveillance of nosocomial infections in Ankara Training and Research Hospital. Journal of Hospital infection.2006;64(4):391-96.

12. Dincer M, Kahveci K, Doger C. An Examination of Factors Affecting the Length of Stay in a Palliative Care Center. J Palliat Med. 2018;21(1):11-5.

13. Yürüyen M, Tevetoğlu IÖ, Tekmen Y, Polat Ö, Arslan İ, Okuturlar Y. Prognostic Factors and Clinical Features in Palliative Care Patients. Konuralp Medical Journal. 2018;10 (1):74-80.

14. Komaç A, Elyiğit F, Türemiş C, Gram E, Akar H. Retrospective analysis of hospitalized patients in Tepecik Training and Research Hospital Internal Medicine Palliative Care Unit. FNG \& Bilim University Journal of Medicine. 2016;2:1-3

15. Turgut Ö, Pektaş M, Aydinli, B, Sagün A. Retrospective analysis of hospital patient in the Mersin City Education and Research Hospital Adult Palliative Care Unit. Mersin Üniversitesi Sağlık Bilimleri Dergisi. 2019;12(3);407-12.

16. Chun ED, Rodgers PE, Vitale CA, Collins CD, Malani PN. Antimicrobial use among patients receiving palliative care consultation. American Journal of Hospice and Palliative Medicine. 2010;27(4):261-65.

17. Pereira J, Watanabe S, Wolch G. A retrospective review of the frequency of infections and patterns of antibiotic utilization on a palliative care unit. J Pain Symptom Manage.1998;16(6):374-81.

18. Dagli O, Tasdemir E,Ulutasdemir N. Palliative care infections and antibiotic cost: a vicious circle. The Aging Male. 2020;23(2):98-105.

19. Akdoğan D, Kahveci K. Evaluation of geriatric infectiıns in palliıative care center. Turkish Journal of Geriatrics. 2018;21(4):507-14.

20. Vitetta L, Kenner D, Sali A. Bacterial infections in terminally ill hospice patients. J Pain Sympt Manag. 2000;20:326-34. 